\title{
Subsidies and Agricultural Productivity in the EU*
}

\author{
Maria Garrone, ${ }^{1}$ Dorien Emmers, ${ }^{1}$ Hyejin Lee, ${ }^{1}$ \\ Alessandro Olper, ${ }^{1,2}$ and Johan Swinnen ${ }^{1,3,4}$ \\ ${ }^{1}$ LICOS Centre for Institutions and Economic \\ Performance \& Department of Economics, \\ KU Leuven, Leuven, Belgium \\ ${ }^{2}$ Department of Environmental Science and \\ Policy, University of Milan, Milan, Italy \\ ${ }^{3}$ CEPS Centre for European Policy Studies, \\ Brussels, Belgium \\ ${ }^{4}$ Higher School of Economics, Moscow, \\ Russia
}

\begin{abstract}
This paper investigates the relationship between EU agricultural subsidies and agricultural labour productivity growth by estimating a conditional convergence growth model. We use more representative subsidy indicators and a wider coverage (panel data from 213 EU regions over the period 2004-2014) than have been used before. We find that, on average, CAP subsidies increase agricultural labour productivity growth, but this aggregate effect hides important heterogeneity of effects of different types of subsidies. The positive effect on productivity comes from decoupled subsidies, i.e. Pillar I decoupled payments and some Pillar II payments. Coupled Pillar I subsidies have the opposite effect: they slow down productivity growth.
\end{abstract}

Keywords: agricultural labor productivity, agricultural subsidies, conditional convergence growth model, panel data analysis.

JEL Classifications: J24, O13, Q10, Q18.

\footnotetext{
* Uncorrected proof of Garrone M, Emmers D, Lee H, Olper A, Swinnen J. Subsidies and agricultural productivity in the EU. Agricultural Economics, 2019;50:803-817. https://doi.org/10.1111/agec.12526.
} 


\section{Introduction}

Traditional economic theory and policy analysis posit that agricultural subsidies distort incentives and reduce productivity (Johnson, 1973; OECD, 2008). However, theoretical and empirical studies have shown that this is not always the case. Subsidies may enhance agricultural productivity in the presence of imperfections in credit or insurance markets (e.g. Ciaian and Swinnen, 2009; Hennessy, 1998; Roche and McQuinn, 2004). A recent review concludes that some studies find positive, other negative effects, and some find no effect of subsidies on agricultural productivity (Minviel and Latruffe 2017). These different findings may be due to variations in rural market imperfections, or to differences in the nature of the subsidies. Different types of agricultural subsidies cause different distortions and may thus have different productivity impacts (e.g. Latruffe et al., 2009; Rizov et al., 2013). These differential effects are important to understand for policy-makers when they consider reforms of agricultural policy to reduce market distortions or to make agricultural policies consistent with sustainability, resilience and climate change objectives.

Our paper contributes to this literature by analysing the impact of the more than 50 billion euros annual subsidies of the EU's Common Agricultural Policy (CAP) on agricultural productivity. In comparison with previous studies, we (a) use more accurate and complete CAP subsidy data, (b) disaggregate subsidy payments into payments of specific subsidy instruments, (c) have a wider coverage of EU regions, including the new member states (NMS), and (d) cover a longer and more recent time period than has been used before. Specifically, we use the Clearance Audit Trail System (CATS) dataset which includes all farm subsidies and details on the types of payments for all subsidy categories. Our analysis uses a regional conditional convergence model and covers the 2004-2014 period and 213 regions of 
the EU-27 (compared to previous studies that covered EU-15 only) ${ }^{1}$ allowing to better test for regional heterogeneity effects for subgroups of countries and for different subsidy types.

Key results are that CAP subsidies, as a whole, have a positive impact on labour productivity in agriculture but that there are important differences in the impact of different types of subsidies. The positive effect comes from decoupled subsidies, i.e. Pillar I decoupled payments and Pillar II payments. Coupled Pillar I subsidies have the opposite effect: they slow down productivity growth.

The paper is structured as follows. In the next section, we give an overview of the literature on subsidies and agricultural productivity. In Section 3 we discuss our empirical approach. In Section 4, we describe our dataset and variable construction. Results are presented in Section 5. Section 6 concludes.

\section{Subsidies and agricultural productivity: Related literature}

Improvements in agricultural labour productivity over time typically result from the movement of workers from farm to non-farm occupations, a process driven by relatively higher wages and productivity in urban jobs, accommodated by adoption of labour-saving techniques of production by farmers. This process is supported by investments in agricultural research, development and extension (see e.g. Gardner 2002). Agricultural subsidies may affect this process.

Agricultural subsidies can reduce agricultural productivity growth by causing allocative and technical efficiency losses: (i) farmer investment decisions may be distorted towards relatively less productive activities that are supported by subsidies (Alston and James, 2002); (ii) farmers may over-invest in subsidised inputs (Rizov et al., 2013); (iii) subsidies

\footnotetext{
${ }^{1}$ Today there are $28 \mathrm{EU}$ member states. The 15 "old" member states (OMS, also often referred to as "EU-15") joined the EU before 2004; the 13 "new" member states (NMS) joined since 2004. More specifically, Cyprus, the Czech Republic, Estonia, Hungary, Latvia, Lithuania, Malta, Poland, Slovakia and Slovenia joined in 2004, Bulgaria and Romania in 2007. Croatia, which joined the EU most recently in 2013, is not included as CATS data are not available for the period covered in our analysis.
} 
may reduce a farmer's incentive to adopt cost-optimising strategies (Leibenstein, 1966; Minviel and Latruffe, 2017); or (iv) subsidies may lead to soft budget constraints, causing inefficient use of resources (Kornai, 1986).

However, some studies have argued that subsidies may also stimulate productivity growth under specific conditions, and that the nature of the subsidies may play a role. Theoretical arguments that subsidies may enhance agricultural productivity are based on the impact of subsidies on farm constraints due to rural market imperfections. With (rural) capital market imperfections, subsidies may help overcome financial constraints of farmers (directly by boosting a farmer's financial resources and indirectly by improving access to credit), which may enhance farm productivity (Blancard et al., 2006; Ciaian and Swinnen, 2009). With imperfect insurance markets, subsidies may mitigate risk and trigger investment in certain types of activity which the farmer may otherwise consider too risky (Hennessy, 1998; Roche and McQuinn, 2004). In both cases, productivity could increase with subsidies.

Empirical evidence is also mixed. Minviel and Latruffe (2017) review studies on the impact of subsidies on farms' technical efficiency and conclude that some studies find positive, other negative effects, and some find no effect of subsidies on agricultural productivity. This does not have to come as a surprise. Given that the theoretical arguments of the potential positive effect of subsidies are based on market imperfections, one would expect these potential positive effects to be stronger when these market imperfections are more important, and vice versa. Hence, one could imagine that the credit-enhancing effects of subsidies could be more important in cases such as when the new member states (NMS) joined the EU in the mid-2000s, as credit constraints were very important for farms in those regions in that period (Ciaian and Swinnen, 2009).

Another potential explanation for heterogeneous effects is the nature of the subsidies. Within the EU's Common Agricultural Policy (CAP) (and in agricultural subsidy discussions 
globally) a crucial differentiation is between "coupled" and "decoupled" subsidies. Coupled subsidies have traditionally been identified as the main source of distortion in agricultural markets due to efficiency losses. As they are tied to output, coupled support is likely to distort input and/or output allocation. The effect of decoupled subsidies may be different as they do not directly affect farmers' product choices, so are less likely to cause inefficiency (Dewbre et al., 2001; Guyomard et al., 2004; Rizov et al., 2013). Empirical studies indeed find (a) negative correlations between coupled subsidies and various measures of productivity (Latruffe et al., 2009; Zhu and Oude Lansink, 2010; Zhu et al., 2012; Mary, 2013) and (b) that agricultural productivity in the EU increased with the shift from "coupled" to "decoupled" subsidies (Mary, 2013; Rizov et al., 2013; Kazukauskas et al., 2014). However, there are counter examples. Indeed, Gardner (2005) working with a cross-section of countries in the period 1980-2001, showed that the level of agricultural support measured by the producer support estimate (PSE), was positively correlated with agricultural productivity growth, in a sample of about 27 countries, mainly OECD countries. ${ }^{2}$

Other studies have also argued that there may be heterogeneous effects for different types of rural development subsidies (so-called Pillar II payments in the CAP). First, the impact of less favoured areas (LFA) payments, granted to farms solely on the basis of their unfavourable geographic location, on agricultural productivity is ex ante not clear. On the one hand, LFA payments may keep inefficient farms going, thereby reducing efficiency (Latruffe and Desjeux, 2016). On the other hand, this type of payments may help maintain agricultural land in good condition by ensuring that agricultural land remains cultivated in areas with poor natural agricultural endowments, thereby enhancing efficiency (Knific and Bojnec, 2010; Latruffe and Desjeux, 2016). Moreover, Baráth, Fertő and Bojnec (2018) found no significant difference in the technical efficiency between LFA and non-LFA farms in Slovenia, but they

\footnotetext{
${ }^{2}$ Note, Gardner (2005) used PSE data averaged over the 1985-1989 period in his growth regression, hence a mix of the commodity price support policy and coupled farm income subsidies were covered.
} 
did find differences in the use of production-environment-specific technologies (e.g., adoption of less intensive technologies in areas with low soil fertility). This means that LFA payments may improve efficiency by allowing farmers to adopt technologies that offset negative impacts of LFA conditions on productivity.

Furthermore, Pillar II payments for investments in human and physical capital may be productivity enhancing and cost-reducing, as improved knowledge of efficient farming practices can lead to better use of technology and land (Boulanger and Philippidis, 2015; Dudu and Kristkova, 2017). Agri-environmental measures are generally assumed to have a negative effect on productivity as they impose constraints on input use (such as fertilizers, pesticides and land). However, empirical evidence on the productivity effect of agrienvironmental payments is mixed. Some find a negative effect on productivity (Lakner, 2009), while others find no or a positive effect (Mary, 2003; Dudu and Kristkova, 2017). Finally, wider rural development payments may have no effect on farming itself, but support other sectors such as rural infrastructure and tourism.

In summary, the impact of CAP payments on agricultural productivity is likely to differ by the geographic region and the type of subsidy considered. The expected net impact depends on the relative size of the different sub-effects.

\section{Empirical approach}

\subsection{Theoretical model}

To analyse the impact of CAP on regional productivity growth patterns, we use a conditional $\beta$-convergence equation in a dynamic panel data framework. This approach follows, for 
example, Rizov $(2005)^{3}$ and other empirical studies that rely on the neoclassical growth model (Solow, 1956) and implement growth regressions which allow to include a larger set of explanatory variables and test for convergence (Barro, 1991; Barro and Sala-i-Martin, 1995). ${ }^{4}$ The method has been popularized by Barro and Sala-i-Martin's (1991) through the estimation of what they call $\beta$-convergence hypothesis, ${ }^{5}$ namely the idea of the Solow (1961) model according to which there should exist a negative relationship between the growth rate of productivity and the initial level of productivity. ${ }^{6}$

According to neoclassical growth theory, there are two types of convergence (Barro and Sala-i-Martin, 1995): absolute convergence and conditional convergence. The absolute convergence hypothesis assumes that, regardless of the initial conditions, in the long term the productivity growth in all economies (countries/regions) converges to the same steady state. The conditional convergence hypothesis contends that if economies have different structural characteristics and growth factors, then convergence is conditional on these parameters, giving rise to different steady states. ${ }^{7}$

The use of a conditional convergence model has a number of advantages. First, it has a stronger theoretical base for productivity growth assessments, drawing on the seminal contributions of Solow $(1956,1957)$ and Swan (1956) and a variety of applications in growth

\footnotetext{
${ }^{3}$ Rizov (2005) uses an augmented neoclassical Solow growth model to analyse the impact of farm individualization in transition economies, so the variables of interest (and geographic focus) differ.

${ }^{4}$ For a review of the convergence literature, see Islam (2003) and Snowdon and Vane (2005).

${ }^{5}$ Barro and Sala-i-Martin's (1991) also introduced the notion of $\sigma$-convergence, which refers to decreasing cross-country dispersion in productivity, i.e. differences in productivity levels becoming smaller over time. Another approach is the time series approach, which is mostly based on stochastic approaches like cointegration (Gáspár, 2012).

${ }^{6}$ Either cross-sectional and panel data models can be used to test $\beta$-convergence hypotheses (see Caselli et al. (1996) for a discussion). In the case of a dynamic panel framework, the negative relationship to test is between the actual growth in productivity, over a period of one to five years, and the initial productivity level, lagged one to five years, respectively.

${ }^{7}$ Depending on whether absolute or conditional hypothesis is tested, there are two different types of $\beta$ convergence. If the $\beta$-convergence model is regressed on the lagged values of the dependent variable alone, then it is an "absolute" $\beta$-convergence model. On the other hand, if the $\beta$-convergence model is regressed on other explanatory variables, to identity factors which could foster productivity to converge, it is a "conditional" $\beta$ convergence model. An alternative type of conditional convergence is club-convergence, where convergence applies to only restricted groups of similar economies (Baumol, 1986; Galor, 1996).
} 
models (see Barro and Sala-i-Martin (1991)). Second, studies have provided empirical evidence in support of agricultural productivity convergence in the EU. ${ }^{8}$ However only a few studies have used the convergence growth model to study the impact of the CAP on agricultural productivity in the EU. These studies (Sassi, 2010; Montresor et al., 2011; Cuerva, 2012) used data for a restricted number of EU countries (EU-15) from at most two time periods (and thus used cross-sectional estimation methods) which did not cover the recent shift from coupled to decoupled subsidies. Since our analysis uses a wider set of countries (EU-27), better subsidy indicators, and ten years of annual data, this allows to estimate a dynamic panel model by means of an appropriate generalized method of moments (GMM) estimator (Caselli et al., 1996; Bond et al., 2001) which is crucial to control for unobserved heterogeneity, dynamic issues, and reverse causation in our key policy variable of interest, i.e. the CAP support rate.

Finally, though our conditional convergence equation has its logical derivation from the neoclassical growth model, both applications of neoclassical and endogenous growth models can be appropriate for explaining convergence and non-convergence behaviour. Throughout the convergence debate, the neoclassical and the endogenous growth models have evolved and the boundaries between the explanation for convergence and non-convergence behaviour in both theories have faded (Islam, 2003). The empirical evidence does not unanimously favour either of these growth theories (Esposti, 2007). Nevertheless, the geographical setting of this study in the EU, where a single market is pursued, fits well with the key assumption of the neoclassical model that is based on the idea that technological progress, being exogenously given, is similar for all regions.

\footnotetext{
${ }^{8} \mathrm{~A}$ number of studies provided evidence for convergence in agricultural productivity in EU regions. These studies include Paci (1997), Alexiadis (2010), Sondermann (2014), and Baráth and Fertő (2017). Other studies focused on regional convergence within specific EU countries (e.g., Esposti (2010) for Italy) or made extra-EU comparisons (e.g., Schimmelpfennig and Thirtle (1999); Gutierrez (2000), Ball et al. (2001), and Rezitis (2010) compared the EU with the US).
} 


\subsection{Estimation strategy}

We estimate a conditional $\beta$-convergence analysis using the following reduced form dynamic panel model:

$$
\Delta y_{i t}=\beta y_{i t-1}+\xi C S_{i t-1}+\delta^{\prime} X_{i t-1}+\gamma_{t}+\mu_{i}+\varepsilon_{i t}
$$

where $\Delta y_{i t} \equiv \ln Y_{i t}-\ln Y_{i t-1}$, denotes region $i$ 's agricultural labour productivity growth between time $t$ and $t-1 ; y_{i t-1}$ is the lagged log agricultural value added (VA) per worker, i.e. the convergence term. Our variable of interest is the agricultural subsidy rate $C S_{i t-1} . X_{i t-1}$ is a vector of control variables that may also affect labour productivity, such as the logarithm of the labour force growth (LF), the logarithm of the population density (PD) and additional regional expenditures of the EU Structural and Investment Funds (ESIF). ${ }^{9}$ The subsidy variables as well as the other covariates enter the equation lagged by one year. This reflects the assumption that farmers need time to adjust to a new situation, e.g. a farmer's choice to leave at time $t$ is affected by the level of CAP payments at time $t-1$. To control for potential endogeneity bias due to omitted variables, we include regional and time fixed effects, $\mu_{i}$ and $\gamma_{t}$, respectively.

Using standard OLS or fixed effects (FE) estimators, will generate biased estimates in the regression coefficients, because the lagged dependent value is correlated with the model's error term $\varepsilon_{i t}$ (Nickell, 1981). In AR(1) panel models, the OLS estimator is in general found to be biased upwards, while the fixed effects estimator is found to be biased downwards (see Bond et al., 2001).

\footnotetext{
${ }^{9}$ Most EU funding is delivered through the five ESIF: European Regional Development Fund (ERDF), Cohesion Fund (CF), European Agricultural Fund for Rural Development (EAFRD)/ the former European Agricultural Guarantee and Guidance Fund (EAGGF), European Social Fund (ESF) and European Maritime and Fisheries Fund (EMFF). They are jointly managed by the European Commission and the EU countries. They are designed to invest in job creation and growth. Our ESIF variable covers all funds, except for the EAFRD - to avoid double counting with our CAP payment data - and the EMFF -for which data are unavailable.
} 
The most widely used approach to account for unobserved individual country (region) effects and to deal with endogeneity of some regressors is applying estimation techniques based on the generalized method of moments (GMM) (Arellano and Bond, 1991; Blundell and Bond, 1998). Particularly, we rely on the two-step system GMM (SYS-GMM) estimator proposed by Blundell and Bond (1998) with Windmeijer's correction method for the variance-covariance matrix. ${ }^{10}$ The SYM-GMM estimator is an extension of the first generation of GMM models using transformations in first differences (DIFF-GMM). ${ }^{11}$

The estimated relationship between agricultural productivity growth and CAP payments could, to a certain extent, be affected by simultaneity bias, as CAP payments are not assigned randomly to farmers (or regions). This issue is particularly relevant for coupled Pillar I payments. Past productivity of farms and regions directly affects the allocation of coupled Pillar I payments. The relationship between productivity and decoupled payments may also be subject to endogeneity. The allocation of decoupled Pillar I payments is not directly linked to current regional production activities, but the allocation of these payments among member states is based on the average amount of coupled payments received during the reference period (2000-2002) preceding the introduction of the 2003 CAP reforms. ${ }^{12}$ This implies that regions that were more productive and/or produced more subsidized output in the past receive higher decoupled payments today (and in the period of our analysis).

While this (potential) source of endogeneity bias is certainly something to be concerned about, there are a number of reasons why such bias, if present, is likely to be (very) small in

\footnotetext{
${ }^{10}$ Monte Carlo studies (e.g., Blundell and Bond, 1998) show that the two-step GMM estimator is asymptotically more efficient than the first step estimator but it may yield downward biased results in small samples. To deal with this potential bias, Windmeijer (2005) proposes a finite sample correction for the variance-covariance matrix in the two-step GMM estimator.

${ }^{11}$ DIFF-GMM has been proven to perform poorly in small $\mathrm{T}$ and large $\mathrm{N}$ panels (Bond et al., 2001). Since our dataset includes almost 1600 observations (i.e. large N) over a 10-year period (i.e. small T), we decided not to use this type of model.

12 This aspect is particularly relevant for the OMS that already received CAP support before the 2003 reforms. However, a similar argument holds for the decoupled support system in the NMS, i.e. the Single Area Payment Scheme (SAPS). The SAPS was not based on farm productivity directly, yet it was linked to the pre-accession average country/regional productivity in the NMS (Ciaian et al., 2015).
} 
our empirical analysis. First, since our estimation model uses as a dependent variable a year to year change in agricultural labour productivity in a recent period (2004-2014) and not productivity levels, it is not obvious that the relationship between this growth variable and differences in the allocation of current coupled/decoupled payments could be affected by potential endogeneity coming from past yield levels (of more than ten years earlier in the case of decoupled payments). In other words, this endogeneity bias would be a more serious issue if we would relate changes in the allocation of subsidy payments to productivity levels rather than to changes in productivity. Second, as discussed in Olper et al. (2014) and Garrone et al. (2019), the assumption of the exogeneity of our (lagged) CAP subsidy rate variable, $C S_{i t-1}$, can be justified on the ground that CAP policy instruments (and their distribution among member states) are allocated by EU authorities rather than by regional authorities (Pillar I) or through negotiations between the EU and national authorities (Pillar II). ${ }^{13}$ Third, all the CAP subsidy variables are lagged by one year, which reduces the potential bias caused by a spurious correlation due to shocks simultaneously affecting CAP payments and agricultural output.

Despite these arguments suggesting that the potential for endogeneity bias between agricultural labour productivity growth and the CAP subsidy rate is limited, we decided to apply a SYS-GMM model in order to rule out any residual component of endogeneity bias. CAP subsidy variables are treated as endogenous in this SYS-GMM model, using the $t-2, t-3$ and longer lag levels (and differences) as instruments. The SYS-GMM model used in our analysis has the advantage to better control for simultaneity bias (Wintoki et al., 2012; Ullah et al., 2018) that might persist even after lagging explanatory variables (Bellemare et al., 2017).

\footnotetext{
${ }^{13}$ More specifically, the CAP is financed by two funds: the European Agricultural Guarantee Fund (EAGF) and the EAFRD, and up until financial year 2006 the EAGGF.
} 


\section{Data and variables}

Our dataset covers $27 \mathrm{EU}$ member states and 213 regions over the period 2004-2014. The choice of the period of analysis (2004-2014) is due to data availability. The (CATS) subsidy data were available only from 2004; and the agricultural productivity data coming from the Cambridge Econometrics Regional Database (CERD) were available only until 2014.

The data were aggregated based on the Nomenclature of Territorial Units for Statistics $(\mathrm{NUTS}){ }^{14}$ at NUTS2 level with the exception of Denmark, Germany, Slovenia, and the United Kingdom, for which NUTS1 level of aggregation was applied. ${ }^{15}$ We had to drop some regional observations due to the lack of data for some variables employed in our econometric analysis, and two strong outliers. ${ }^{16}$ This resulted in a final sample consisting of 1,587 observations and 213 regions.

\subsection{Agricultural labour productivity growth (dependent variable)}

We use CERD data to measure productivity growth in agriculture as annual growth in gross agricultural VA (VA-Agr.) per worker in real terms, where workers are defined as all persons engaged in some productive agricultural activity. ${ }^{17}$ Gross agricultural VA embodies the productivity effect induced by (coupled) CAP payments.

\footnotetext{
${ }^{14}$ The NUTS is a geographical nomenclature subdividing the economic territory of the EU into regions at three different levels: NUTS1, NUTS2, and NUTS3, respectively, moving from larger to smaller territorial units (Eurostat, 2013).

${ }^{15}$ The choice of employing NUTS1 level data for Germany and the UK is based on the fact that these countries adopted a regional approach to the implementation of both CAP and structural fund policies at NUTS1 level. As for Denmark and Slovenia, the choice of employing NUTS1 level is due to the fact that agricultural subsidy data are not available at NUTS2 level for the entire period of analysis.

${ }^{16}$ We dropped two observations based on a number of diagnostic tests. Partial-regression plots and the DFBETA test in STATA clearly identify the values of CAP subsidies for the Border, Midland and Western region in 2013 and the Bucharest region in 2010 as outliers. Our main results remain robust to the inclusion of these outliers. See Appendix A for the result after inclusion of these outliers.

${ }^{17}$ Although labour productivity is a partial measure of productivity, this measure is still a main element of differences in the economic performance of regions and regional 'competitiveness' (Martin, 2001).
} 
The average rate of agricultural labour productivity growth is around $1.3 \%$ in the EU as a whole (see Table 1). The growth rate in NMS (3.2\%) is more than four times higher than in the OMS $(0.8 \%)$. These growth differences are consistent with a process of convergence in productivity level between NMS and OMS.

In order to avoid endogeneity bias, we need a measure of the growth in agricultural VA per worker that is net of the effect of coupled CAP subsidy payments, as this component of payments are included in the computation of agricultural VA (see European Commission, 2000). In principle, we can compute agricultural VA net of the effect of coupled payments by subtracting this CAP subsidy component from the agricultural VA. However, this approach implicitly assumes that the transfer efficiency of CAP payments is 100 percent, while studies have shown that the transfer efficiency is often lower, due for example to capitalization of CAP payments in land rents. Thus, following Olper et al. (2014) we measure agricultural labour productivity growth net of the effect of coupled CAP subsidies by first regressing the agricultural productivity growth (the dependent variable) on the coupled CAP subsidy component, and then keeping the residuals from that regression. Note, in the observed period coupled CAP subsidy significantly decrease starting from 2005 onward, because as an effect of the Fischler Reform they are largely substituted by decoupled CAP subsidy. So that this adjustment in the productivity growth rate, is relevant only in the first two years of our data. Importantly, without this adjustment, all regression results of the paper are qualitatively and quantitatively similar.

\subsection{Agricultural subsidy rate}

The key variable in the regression equation, $C S_{i t-1}$, is the agricultural subsidy rate, which, as in previous analysis, is calculated as the ratio of agricultural subsidies over 
agricultural VA at regional level. ${ }^{18} \mathrm{We}$ compute the ratio between regional CAP payments and regional agricultural VA, because this ratio provides us with a consistent indicator of regional agricultural protection due to CAP policy measures.

What is different in our study is that we calculate the regional CAP payments with data from the CATS database ${ }^{19}$ aggregated at NUTS2 regional level. The CATS database includes information on payments of each individual budget component of the CAP funds to all farms that receive payments. To the best of our knowledge, only Dudu and Kristakova (2017) use CATS data in their analysis of the impact of CAP payments on agricultural productivity. They only focus on the impact of CAP Pillar II payments over a short period of analysis.

The CATS data include details on all payments made to all recipient farmers for each individual budget component of the CAP funds. Previous studies of EU agricultural productivity typically constructed subsidy indicators using the dataset of the Farm Accountancy Data Network (FADN), which covers only agricultural holdings whose size exceeds a minimum threshold. Using CATS data reduces the sample selection bias inherent to studies based on FADN data. Second, the CATS data allow to distinguish (a) between Pillar I and Pillar II payments; (b) within Pillar I support between decoupled and coupled payments; and (c) within Pillar II payments between five classes of payments (for which we follow the categorization of Boulanger and Philippidis (2015)). This allows to test whether these various types of payments have different effects on agricultural productivity growth. Third, our analysis covers 213 regions of the EU-27 (as compared to previous studies that covered EU-

\footnotetext{
${ }^{18}$ Other studies relating agricultural productivity (efficiency) to this subsidy rate are for example Fogarasi and Latruffe (2009) and Bakucs et al. (2010). See Minviel and Latruffe (2017) for an overview.

19 The CATS was created to assist the European Commission in implementing audits on agricultural expenditures. It collects the digitalized files that each member state forwards to the European Commission concerning details of all individual payments (in euro) made to CAP recipients.
} 
15 regions). ${ }^{20}$ This allows to disentangle effects for subgroups of countries and, in particular, whether there are differences between old member states (OMS) and NMS. Fourth, we use ten years of annual data starting from the year when the NMS acceded to the EU (2004-2014). The post-NMS accession period was not covered in previous studies.

Of course, concerning the use of CATS data, we should also mention that by including farm activities related to smaller farms may entail a number of drawbacks, at least to the extent that activities of "hobby" farmers with substandard efficiency levels are concerned. However, a critical point of our econometric exercise that differentiates our paper from analyses conducted at the farm level, is the possibility to generalize our results for the full population of farmers. This is an important point because agricultural subsidies have both direct and indirect effects. Indirect effects operate mainly through the adjustment of factor markets and output prices (see, e.g. Pufhal and Weiss, 2009). Thus by working at the aggregated (regional) level and considering the true amount of money related to the different policy measures targeted at each territorial unit, we are able to fully capture the indirect effects of agricultural policy in our analysis. ${ }^{21}$

To address potential endogeneity bias that might arise from having VA on both sides of our empirical model we lag the subsidy variables by one year and treat the CAP subsidy rate as endogenous in the applied SYS-GMM model.

\footnotetext{
${ }^{20}$ Today there are 28 EU member states. The 15 "old" member states (OMS, also often referred to as "EU-15") joined the EU before 2004; the 13 "new" member states (NMS) joined since 2004. More specifically, Cyprus, the Czech Republic, Estonia, Hungary, Latvia, Lithuania, Malta, Poland, Slovakia and Slovenia joined in 2004, Bulgaria and Romania in 2007. Croatia, which joined the EU most recently in 2013, is not included as CATS data are not available for the period covered in our analysis.

${ }^{21}$ It is worth noting that by using CATS instead of FADN data to measure CAP subsidy rates, the differences in the level of support is substantial. For example, considering the overall CAP payments (Pillar I and PillarII), the average amount of agricultural support related to agricultural value added, is equal to $32 \%$ using CATS data, a value that goes up to $51 \%$ when using FADN data. This is a considerable difference that cannot be attributed to the inclusion of "hobby" farmers. Importantly, the difference between the two types of subsidy indicators (CATS vs. FADN), is not only cause by the difference in levels of subsidy payments, but also in differences in the growth rate over time. This problem is particularly important for the NMS (see Table 1 in Garrone et al. (2019)). This is at odds with an empirical framework that exploits within region variation in agricultural protection rates for identification.
} 


\subsection{Different types of agricultural subsidies}

The CATS database allows to disaggregate total CAP payments into several components to test whether the impact on agricultural employment differs among types of agricultural subsidies. First, within Pillar I support we distinguish between coupled and decoupled payments. Coupled payments are those linked to the production of a specific crop or animal commodities. Over the last decade, reforms have generally moved the CAP away from coupled payments. Most of the Pillar I payments are now decoupled from production. The residual component of coupled subsidies, linked to production, represents a small fraction of the overall support.

Second, within Pillar II payments we distinguish between five categories, following Boulanger and Philippidis (2015): (a) investment in human capital (HK); (b) investment in physical capital (PK); (c) agri-environmental payments (ENV); (d) LFA payments; and (e) wider rural development (RD) instruments. ${ }^{22}$

\subsection{Control variables}

Control variables include changes in the agricultural labour force, population density, GDP growth, share of large farms, and share of grassland. Data for these variables are obtained from the CERD and Eurostat. ${ }^{23}$ As is common in the growth literature, the growth of the agricultural labour force is calculated as the difference between the $(\log )$ labour force in year $t$ minus the $(\log )$ labour force in year $t-1$, then adjusted by the common exogenous rate of

\footnotetext{
${ }^{22}$ The wider rural development measures include payment for diversification into non-agricultural activities, encouragement of rural tourism, and village renewal and development.

${ }^{23}$ Data on agricultural labour force growth, population density, and regional GDP are obtained from CERD. Data on the share of large farms and the share of grassland are obtained from Eurostat.
} 
technical change and the common depreciation rate, the sum of which is assumed to be 0.05 (Mankiw et al., 1992).

The growth rate of regional GDP is an indicator of regional economic conditions and development. The regional share of large farms and the ratio of grassland over the total utilized agricultural area are both indicators of farm structure and production structure. As Glauben et al (2006) we add population density, calculated as the total population over regional area in $\mathrm{km}^{2}$, as control indicator for market conditions, such as the level of activity in product and factor markets, with activities expected to more intense and imperfections lower in areas with higher population density.

To control for other types of (non-agricultural) EU support to the region, we also include a variable covering ESIF spending. We use annual EU expenditures of the ERDF, the $\mathrm{CF}$, and the ESF at the NUTS2 level of regional aggregation per unit of regional GDP. ${ }^{24}$ According to Esposti (2007) these expenditures can be considered as mostly consisting of investment. Descriptive statistics in Table 1 indicate that ESIF, on average, accounts for a larger share of regional GDP in NMS than in OMS. Few previous studies have controlled for these payments, but these payments could influence the results if they are correlated with CAP subsidies (due to omitted variable bias). We later test the robustness of our results by running the models with and without this control variable.

\section{Results}

Tables 2 to 4 report the estimation results for the EU-27 (Table 2), OMS (Table 3), and NMS (Table 4). In each table, Column 1 presents SYS-GMM regression results with the total CAP subsidy rate as the main explanatory variable. Columns 2 to 4 present SYS-GMM regressions

\footnotetext{
${ }^{24}$ ESIF data come from the DG REGIO website https://cohesiondata.ec.europa.eu/EU-Level/Historic-EUpaymentsregionalised-and-modelled/tc55-7ysv. Regional GDP data come from the CERD.
} 
results with CAP expenditures disaggregated into Pillar I and Pillar II (Column 2); and further into "coupled Pillar I subsidies" and "decoupled Pillar I subsidies" (Column 3) and the five components of Pillar II (Column 4).

Column 5 presents results using OLS and Columns 6 using FE with total CAP subsidies - to compare with the SYS-GMM estimates in Column 1. The SYS-GMM (Column 1) point estimates of the lagged dependent variable (i.e. the one year lagged agricultural VA per worker) fall within the range of the OLS (Columns 5) and FE (Column 6) point estimates, suggesting that the SYS-GMM estimator yields consistent estimates (Bond et al., 2001).

Standard tests for consistency of the SYS-GMM estimators are reported at the bottom of Tables 2-4. The Arellano-Bond tests $\mathrm{AR}(1)$ and $\mathrm{AR}(2)$ indicate the absence of first-order autocorrelation, indicating that the dynamic model is correctly specified. The $p$-value of Hansen's test suggests that we cannot reject the null hypothesis of the (joint) validity of our instruments at the $5 \%$ level of significance. ${ }^{25}$

Key results on the impact of CAP subsidies on productivity are the following. The total CAP subsidy rate (Column 1) has a positive and significant coefficient for all three regional specifications (EU-27, OMS and NMS). Hence, on average, CAP subsidies have a positive impact on EU agricultural productivity growth. However, as the regressions in Columns 2-4 show, the different type of subsidies have very different effects.

Total Pillar I subsidies have no significant positive effect on agricultural labour productivity growth in the EU-27, the OMS, or the NMS. This aggregate result for Pillar I seems to be caused by the opposing effects of decoupled and coupled Pillar I subsidies. The

\footnotetext{
${ }^{25}$ The SYS-GMM estimator requires relatively mild stationarity assumptions. To be specific, the assumption of mean stationarity is required to ensure the consistency of the SYS-GMM estimator under large $N$ and fixed $T$ asymptotics (Blundell and Bond, 1998). Over-identifying restriction tests, such as the Hansen test (Bun and Sarafidis, 2015), can in principle be used to detect violations from mean stationarity. The literature suggests to combine such tests with difference over-identifying restrictions tests (Bun and Sarafidis, 2015). By computation of such differences between DIFF-GMM and SYS-GMM statistics, we detect no violations of the mean stationarity assumption.
} 
estimated effect of decoupled Pillar I subsidies is positive and significant, while coupled Pillar

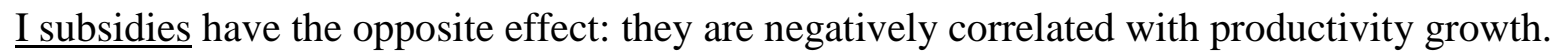

The estimated coefficients of total Pillar II payments are positive, although the effect is not significant in NMS. If we analyse the different components of Pillar II payments (Column 4), we find that in all regions there is a positive and significant effect of Pillar II spending on physical capital (PK). This is the only component for which there is a positive effect on productivity. Hence, these PK payments seem to be cause investment-induced productivity gains; and the only reason why Pillar II payments stimulate productivity.

Two other components of Pillar II payments have a negative effect in some regions, but not significantly for the EU-27 as a whole. The coefficient for LFA payments is significant and negative in the OMS, a result that is in line with earlier empirical findings documenting higher efficiency losses associated with these types of payments (Lakner, 2009; Mary, 2013). Rural development (RD) payments have a negative and significant effect in the NMS. Finally, the coefficient of Environmental payments (ENV) is positive but insignificant for EU-27 as well as for OMS and NMS regressions.

Regarding the control variables, the coefficients of agricultural labour force growth, population density, and the share of large farms are insignificant in the EU-27. GDP growth, the grassland ratio, and ESIF spending are negatively correlated with agricultural labour productivity growth in the EU-27.

The results indicate conditional $\beta$-convergence of productivity among regions. The conditional $\beta$-convergence effect is captured by the estimated coefficient of the (lagged) agricultural VA per worker. The coefficient is always negative and significant in most specifications. Convergence is higher for the NMS $(9.5 \% \sim 36.2 \%)$ than for the OMS $(6.2 \%$ $\sim 15.1 \%$ ). Within the EU-27, the speed of convergence is between $1.8 \%$ and $5.4 \%$ (Columns 1-4 of Tables 2-4). 
A series of additional analyses and robustness tests are presented in Appendix. The additional analyses estimate absolute convergence (Table A.1), test for $\sigma$-convergence (Figure A.1), test for the impact of excluded outliers (Table A.2) and of potentially endogenous control variables (ESIF Payments) (Table A.3). These additional analyses show absolute convergence (in EU-27, OMS, and NMS), no evidence of $\sigma$-convergence ${ }^{26}$ and that that the overall results do not change with outliers and specific control variables. In summary, the results reported above are robust to these modifications and supported by additional analyses.

\section{Conclusions}

This paper estimates the impact of CAP subsidies on EU agricultural labour productivity within a conditional growth convergence framework. We estimate a dynamic model using the SYS-GMM estimator. We use an EU-wide panel dataset covering 213 regions and the 20042014 period, and CATS data with detailed information on CAP payments to farms. We use a SYS-GMM specification where CAP payments are treated as endogenous variables to address issues of potential endogeneity bias related to agricultural subsidies.

We find that CAP subsidies, as a whole, have a positive impact on labour productivity in agriculture in the EU-27, OMS, and NMS. However, this aggregate positive effect hides important differences in the impact of different types of subsidies. The positive effect comes from decoupled subsidies, i.e. Pillar I decoupled payments and Pillar II payments. Coupled Pillar I subsidies have the opposite effect: they slow down productivity growth.

\footnotetext{
${ }^{26}$ Figure A.1 in Appendix shows the dispersion of agricultural productivity across the EU-27 during the period 2004-2014. Since there is no strong downward trend in this dispersion, there is no (strong) evidence of $\sigma-$ convergence. This finding is in line with earlier studies showing that $\beta$-convergence is a necessary, but not a sufficient condition for $\sigma$-convergence (Young, Higgins and Levy, 2008).
} 
These findings support the argument that the CAP reforms of the past decades which have caused a shift from coupled subsidies to decoupled payments in Pillar I and an increase in Pillar II payments have been positive for agricultural labour productivity growth. This is consistent with earlier findings that the shift from "coupled" to "decoupled" subsidies increased agricultural productivity in the EU (Rizov et al., 2013; Mary, 2013; Kazukauskas et al., 2014). With decoupling of support, farmers can shift to production activities with higher value added, and inefficiencies are likely to reduce (Dewbre et al., 2001; Guyomard et al., 2004).

While total Pillar II payments are positively correlated with productivity growth, this effect seems to be caused only by one component: Pillar II spending on physical capital (PK). This is the only component for which there is a positive effect on productivity. Most components have no effect. LFA payments are negatively correlated with productivity in the OMS and rural development (RD) payments negatively correlated in the NMS.

Our results also show conditional $\beta$-convergence of agricultural labour productivity among regions. Convergence is higher for the NMS than for the OMS.

A final caveat is that our results do not necessarily imply that decoupled payments are an efficient policy instrument to stimulate productivity growth in EU agriculture. Our analysis only analyses the "gross effect" of the policy and ignores the costs of the policy and can therefore not evaluate the cost/benefit ratio and the net effect of these policies.

\section{Acknowledgments}

We would like to thank Pavel Ciaian, Tassos Haniotis, Emma Janssen, Alan Matthews, Hans Kordik, Joao PedroWagner De Azevedo, Rogier Van Den Brink, Senne Vandevelde, and four anonymous reviewers for comments on earlier versions of the paper. The authors are solely responsible for the opinions and conclusions expressed in this paper.

\section{Funding information}

KULeuven/Flemish Government, Methusalem Funding;Research Foundation Flanders (FWO), Grant/Award Number: G0G4318N (EOS-contract 30784531). 


\section{References}

Alexiadis, S., 2010. Convergence in Agriculture: Evidence from the European Regions. Agric. Econ. Rev. 11, 84-96.

Alston, J. M., James, J. S., 2002. The Incidence of Agricultural Policy. In B. L. Gardner and G. C. Rausser, eds., Handbook of Agricultural Economics. Elsevier, North-Holland, pp. 1689-1749

Arellano, M., Bond, S., 1991. Some Tests of Specification for Panel Data: Monte Carlo Evidence and an Application to Employment Equations. Rev. Econ. Stud. 58, 277-97.

Ball, V. E., Bureau, J. C., Butault J. P., Nehring, R., 2001. Levels of Farm Sector Productivity: An International Comparison. J. Prod. Anal. 15, 5-29.

Bakucs, L. Z., Latruffe, L., Fertö, I., Fogarasi, J., 2010. The Impact of EU Accession on Farms' Technical Efficiency in Hungary. Post-Communist Econ. 22, 165-75.

Baráth, L., Fertő, I., 2017. Productivity and Convergence in European Agriculture. J. Agric. Econ. 68, 228-48.

Baráth, L., Fertő, I., Bojnec, S., 2018. Are Farms in Less Favored Areas Less Efficient? Agricultural Economics. 49, 3-12.

Barro, R. J., 1991. Economic Growth in a Cross Section of Countries. Q. J. Econ. 106, 40743.

Barro, R. J., Sala-i-Martin, X., 1991. Convergence across States and Regions. Brookings Pap. Econ. Act. 22, 107-82.

—., 1995. Economic Growth. McGraw-Hill, New York

Baumol, W., 1986. Productivity Growth, Convergence, and Welfare: What the Long-Run Data Show. Am. Econ. Rev.76, 1072-85.

Bellemare, M. F., Masaki, T., Pepinsky, T. B., 2017. Lagged Explanatory Variables and the Estimation of Causal Effect. J. Politics. 79(3), 949-63.

Blancard, S., Boussemart, J. P., Briec, W., Kerstens. K., 2006. Short- and Long-Run Credit Constraints in French Agriculture: A Directional Distance Function Framework Using Expenditure-Constrained Profit Functions. Am. J. Agric. Econ. 88, 351-64.

Blundell, R., Bond, S., 1998. Initial Conditions and Moment Restrictions in Dynamic Panel Data Models. J. Econometrics 87, 115-43.Bond, S., Hoeffler, A., Temple, J., 2001. GMM Estimation of Empirical Growth Models. CEPR Discussion Papers 3048.

Boulanger, P., Philippidis, G., 2015. The EU Budget Battle: Assessing the Trade and Welfare Impacts of CAP Budgetary Reform. Food Policy 51, 119-30.

Bun, M. J., Sarafidis, V., 2015. Dynamic panel data models. The oxford handbook of panel data, 76-110.

Bureau, J.-C., Tangermann, S., Matthews, A., Viaggi, D., Crombez, C., Knops, L., Swinnen, J., 2012. The Common Agricultural Policy after 2013. Intereconomics. 47(6), 316-42 
Caselli, F., Esquivel, G., Lefort, F., 1996. Reopening the Convergence Debate: A New Look at Cross-Country Growth Empirics. J. Econ. Growth 1, 363-89.

Cechura, L., Grau, A., Hockmann, H., Levkovych, I., Kroupova. Z., 2016. Catching Up or Falling Behind in European Agriculture: The Case of Milk Production. J. Agric. Econ. 68, 206-27.

Ciaian, P., Swinnen. J., 2009. Credit Market Imperfections and the Distribution of Policy Rents. Am. J. Agric. Econ. 91, 1124-39.

Dewbre, J., Antón, J., Thompton. W., 2001. The Transfer Efficiency and Trade Effects of Direct Payments. Am. J. Agric. Econ. 83, 1204-14.

Dudu, H., Kristkova, Z., 2017. Impact of CAP Pillar II Payments on Agricultural Productivity. Technical Report. European Commission, Joint Research Centre (JRC)

Esposti, R. 2007. Regional Growth and Policies in the European Union: Does the Common Agricultural Policy have a Counter-treatment Effect? Am. J. Agric. Econ. 89, 116-34.

., 2010. Convergence and Divergence in Regional Agricultural Productivity Growth: Evidence from Italian Regions, 1951-2002. Agric. Econ. 42, 153-69.

Eurostat, 2013. History of Nuts. Available at https://ec.europa.eu/eurostat/web/nuts/history.

Fogarasi, J., Latruffe, L., 2009. Farm Performance and Support in Central and Western Europe: A Comparison of Hungary and France. Paper presented at the 83rd Annual Conference of the Agricultural Economics Society. Dublin, Ireland.

Galor, O., 1996. Convergence? Inferences from Theoretical Models. Econ. J. 106, 1056-69.

Gáspár, A., 2012. Convergence Analysis: A New Approach. MPRA Paper. 2012.

Gardner, B., 2000. Economic Growth and Low Incomes in Agriculture. Am. J. of Agric. Econ. 82, 1059-74.Gardner, B., 2002. American Agriculture in the Twentieth Century. Cambridge, MA: Harvard University Press.

Gardner, B., 2005. Causes of Rural Economic Development. Agricultural Economics. 32, 2141.

Garrone, M., Emmers, D., Olper, A., Swinnen, J., 2019. Jobs and Agricultural Policy: Impact of the Common Agricultural Policy on EU Agricultural Employment. Food Policy, forthcoming.

Glauben, T., Tietje, H., Weiss, C., 2006. Agriculture on the Move: Exploring Regional Differences in Farm Exit Rates in Western Germany. Jahrbuch für Regonalwissenschaft. 26, 103-18.

Gutierrez, L., 2000. Convergence in US and EU Agriculture. Eur. Rev. Agric. Econ. 27, 187206.

Guyomard, H., Le Mouël, C., Gohin, A., 2004. Impacts of Alternative Agricultural Income Support Schemes on Multiple Policy Goals. Eur. Rev. Agric. Econ. 31,125-48.

Hennessy, D. A., 1998. The Production Effects of Agricultural Income Support Policies under Uncertainty. Am. J. Agric. Econ. 80, 46-57. 
Islam, N., 2003. What Have We Learnt from the Convergence Debate? J. Econ. Surveys. 17, 309-62.

Johnson, D. G., 1973. World Agriculture in Disarray. Palgrave Macmillan.

Kazukauskas, A., Newman, C., Sauer, J., 2014. The Impact of Decoupled Subsidies on Productivity in Agriculture: A Cross-Country Analysis Using Microdata. Agric. Econ. 45, 327-36.

Knific, K., Bojnec, S., 2010. Agricultural households in mountain areas in pre- and postaccession Slovenia. J. Geogr. 5, 33-42.

Kornai, J., 1986. The Soft Budget Constraint. Kyklos 39, 3-30.

Lakner, S., 2009. Technical Efficiency of Organic Milk-Farms in Germany - the Role of Subsidies and of Regional Factors. International Association of Agricultural Economists Conference, August 16-22, 2009, Beijing, China.

Latruffe, L., Desjeux, Y., 2016. Common Agricultural Policy Support, Technical Efficiency and Productivity Change in French Agriculture. Rev. Agric. Food Environ. Stud. 97, 1528.

Leibenstein, H., 1966. Allocative Efficiency vs. 'X-Efficiency. Am. Econ. Rev. 56, 392-415.

Lucas, R. E., 1988. On the Mechanics of Economic Development. J. Mon. Econ. 22, 3-42.

Mankiw, N. G., Romer, D., Weil, D. N., 1992. A Contribution to the Empirics of Economic Growth. Q. J. Econ. 107, 407-37.

Martin, R., 2001. EMU versus the Regions? Regional Convergence and Divergence in Euroland. J. Econ. Geography 1, 51-80.

Mary, S., 2013. Assessing the Impacts of Pillar 1 and 2 Subsidies on TFP in French Crop Farms. J. Agric. Econ. 64, 133-44.

Matthews, A., 2014. What Is Happening to EU Agricultural Productivity Growth? | CAP Reform. Accessed at http://capreform.eu/what-is-happening-to-eu-agriculturalproductivity-growth/.

Minviel, J. J., Latruffe, L., 2017. Effect of Public Subsidies on Farm Technical Efficiency: A Meta-Analysis of Empirical Results. Applied Econ. 49, 213-26.

Montresor, E., Pecci, F., Pontarollo, N., 2011. The Convergence Process of the European Regions: The Role of Regional Policy and the Common Agricultural Policy. Stud. Agric. Econ. 113, 1-11.

Nickell, S., 1981. Biases in Dynamic Models with Fixed Effects. Econometrica 49, 1417-26.

OECD, 2008. Agricultural Policy Design and Implementation: A Synthesis. Paris, France: OECD.

Paci, R., 1997. More Similar and Less Equal: Economic Growth in the European Regions. Rev. World Econ. 133, 609-34. 
Quah, D., 1996. Empirics for Economic Growth and Convergence. Eur. Econ. Rev. 40, 135375.

Rezitis, A. N., 2010. Agricultural Productivity and Convergence: Europe and the United States. Applied Econ. 42, 1029-44.

Rizov, M., 2005. Does Individualization Help Productivity of Transition Agriculture? Agric. Econ. 33, 215-27.

Rizov, M., Pokrivcak, J., Ciaian, P., 2013. CAP Subsidies and Productivity of the EU Farms. J. Agric. Econ. 64, 537-57.

Roche, M. J., McQuinn. K., 2004. Riskier Product Portfolio under Decoupled Payments. Eur. Econ. Rev. 31, 111-23.

Romer, P. M., 1986. Increasing Returns and Long-Run Growth. J. Pol. Econ. 94, 1002-37. , 1990. Endogenous Technological Change. J. Pol. Econ. 98, 71-102.

Schimmelpfennig, D., Thirtle, C., 1999. The Internationalization of Agricultural Technology: Patents, R\&D Spillovers, and Their Effects on Productivity in the European Union and United States. Contemp. Econ. Pol. 17, 457-68.

Snowdon, B., Vane, H. R., 2005. Modern Macroeconomics: Its Origins, Development and Current State. Edward Elgar Publishing.

Solow, R. M., 1956. A Contribution to the Theory of Economic Growth. Q. J. Econ. 70, 6594.

1957. Technical Change and the Aggregate Production Function. Rev. Econ. Stat. 39, 312-20.

Sokolow, A. D., 2003. California's Edge Problem: Urban Impacts on Agriculture, in J. Siebert, ed., California Agriculture Dimensions and Issues, University of California Giannini Foundation of Agricultural Economics, Division of Agriculture and Natural Resources.

Sondermann, D., 2014. Productivity in the Euro Area: Any Evidence of Convergence? Emp. Econ. 47, 999-1027.

Swan, T.W., 1956. Economic Growth and Capital Accumulation. Econ. Record 32, 334-61.

Swinnen, J., Vranken. L., 2010. Reforms and Agricultural Productivity in Central and Eastern Europe and the Former Soviet Republics: 1989-2005. J. Prod. Anal. 33, 241-58.

Ullah, S., Akhtar, P., Zaefarian, G., 2018. Dealing with Endogeneity Bias: The Generalized Method of Moments (GMM) for Panel Data. Industrial Marketing Management, 71, 6978.

Windmeijer, F., 2005. A Finite Sample Correction for the Variance of Linear Efficient TwoStep GMM Estimators. J. Econometrics 126, 25-51.

Wintoki, M. B., Linck, J. S., Netter, J. M., 2012. Endogeneity and the Dynamics of Internal Corporate Governance. J. Financial Econ. 105(3), 581-606. 
Young, A. T., Higgins, M. J., Levy, D., 2008. Sigma Convergence versus Beta Convergence: Evicence from U.S. County-Level Data. Journal of Money, Credit and Banking. 40(5), 1083-93.

Zhu, X., Demeter, R. M., Oude Lansink, A., 2012. Technical Efficiency and Productivity Differentials of Dairy Farms in Three EU Countries: The Role of CAP Subsidies. Agric. Econ. Rev. 13, 66-92. 
Table 1: Descriptive Statistics

\begin{tabular}{|c|c|c|c|c|c|c|c|}
\hline \multirow[t]{2}{*}{ Variables } & \multirow[t]{2}{*}{ Description } & \multicolumn{2}{|c|}{ EU-27 } & \multicolumn{2}{|c|}{ OMS } & \multicolumn{2}{|c|}{ NMS } \\
\hline & & Obs. & Mean & Obs. & Mean & Obs. & Mean \\
\hline Total CAP payments/VA & \multirow{10}{*}{ Subsidy rate } & 1,587 & 0.349 & 1,276 & 0.341 & 311 & 0.380 \\
\hline Pillar I payments/VA & & 1,587 & 0.265 & 1,276 & 0.276 & 311 & 0.224 \\
\hline Pillar II payments/VA & & 1,587 & 0.083 & 1,276 & 0.066 & 311 & 0.156 \\
\hline Pillar I coupled payments/VA & & 1,587 & 0.095 & 1,276 & 0.113 & 311 & 0.022 \\
\hline Pillar I decoupled payments/VA & & 1,587 & 0.170 & 1,276 & 0.163 & 311 & 0.203 \\
\hline Pillar II HK/VA & & 1,587 & 0.008 & 1,276 & 0.006 & 311 & 0.019 \\
\hline Pillar II PK/VA & & 1,587 & 0.014 & 1,276 & 0.010 & 311 & 0.031 \\
\hline Pillar II ENV/VA & & 1,587 & 0.026 & 1,276 & 0.024 & 311 & 0.036 \\
\hline Pillar II LFA/VA & & 1,587 & 0.015 & 1,276 & 0.013 & 311 & 0.025 \\
\hline Pillar II RD/VA & & 1,587 & 0.015 & 1,276 & 0.011 & 311 & 0.033 \\
\hline Agricultural productivity growth & Growth rate of VA-Agr. per worker & 1,587 & 0.013 & 1,276 & 0.008 & 311 & 0.032 \\
\hline Agricultural employment growth & Growth rate of agricultural employment & 1,587 & -0.015 & 1,276 & -0.012 & 311 & -0.026 \\
\hline Population density & 1,000 person $/ \mathrm{km}^{2}$ & 1,587 & 0.284 & 1,276 & 0.301 & 311 & 0.212 \\
\hline ESIF & ESIF payments/regional GDP & 1,587 & 0.010 & 1,276 & 0.005 & 311 & 0.028 \\
\hline GDP growth & Annual growth rate of regional GDP & 1,587 & 0.009 & 1,276 & 0.006 & 311 & 0.020 \\
\hline Share of large farms & $\begin{array}{l}\text { Share of large farms (with a standard } \\
\text { output of over } 100 \text { thousand euros) in } \\
\text { total number of farms }\end{array}$ & 1,587 & 0.734 & 1,276 & 0.755 & 311 & 0.646 \\
\hline Grassland ratio & $\begin{array}{c}\text { Share of grassland in total utilized } \\
\text { agricultural area }\end{array}$ & 1,587 & 0.344 & 1,276 & 0.369 & 311 & 0.243 \\
\hline
\end{tabular}

Note: ESIF include: ERDF, CF and ESF. Sources: CATS database provided by the European Commission, CERD, DG REGIO, and Eurostat. 
Table 2: Convergence regressions for agricultural productivity in EU-27 (213 regions)

\begin{tabular}{|c|c|c|c|c|c|c|}
\hline $\begin{array}{l}\text { Dependent Variable: } \\
\Delta \text { log VA-Agr. per worker }\end{array}$ & $\begin{array}{c}(1) \\
\text { SYS-GMM }\end{array}$ & $\begin{array}{c}(2) \\
\text { SYS-GMM }\end{array}$ & $\begin{array}{c}\text { (3) } \\
\text { SYS-GMM }\end{array}$ & $\begin{array}{c}\text { (4) } \\
\text { SYS-GMM }\end{array}$ & $\begin{array}{l}5) \\
\text { OLS }\end{array}$ & $\begin{array}{l}\text { (6) } \\
\text { FE }\end{array}$ \\
\hline Total CAP subsidy rate (t-1) & $\begin{array}{c}0.069 * * * \\
(4.11)\end{array}$ & & & & $\begin{array}{l}0.019 \\
(0.86)\end{array}$ & $\begin{array}{l}0.006 \\
(0.28)\end{array}$ \\
\hline Pillar I total (t-1) & & $\begin{array}{l}0.011 \\
(0.30)\end{array}$ & & & & \\
\hline Pillar I coupled (t-1) & & & $\begin{array}{c}-0.040 * * * \\
(6.73)\end{array}$ & $\begin{array}{c}-0.034 * * \\
(2.04)\end{array}$ & & \\
\hline Pillar I decoupled (t-1) & & & $\begin{array}{l}0.119 * * * \\
(3.21)\end{array}$ & $\begin{array}{c}0.124 * * * \\
(4.87)\end{array}$ & & \\
\hline Pillar II total (t-1) & & $\begin{array}{c}0.217 * * * \\
(4.23)\end{array}$ & $\begin{array}{l}0.252 * * * \\
(7.95)\end{array}$ & & & \\
\hline Pillar II HK (t-1) & & & & $\begin{array}{l}0.289 \\
(0.80)\end{array}$ & & \\
\hline Pillar II PK (t-1) & & & & $\begin{array}{c}0.384 * * * \\
(3.80)\end{array}$ & & \\
\hline Pillar II ENV (t-1) & & & & $\begin{array}{l}0.702 \\
(1.30)\end{array}$ & & \\
\hline Pillar II LFA (t-1) & & & & $\begin{array}{l}-1.027 \\
(1.54)\end{array}$ & & \\
\hline Pillar II RD (t-1) & & & & $\begin{array}{l}0.211 \\
(0.61)\end{array}$ & & \\
\hline VA-Agr. per worker (t-1) & $\begin{array}{c}-0.053 * * * \\
(3.33)\end{array}$ & $\begin{array}{l}-0.030 \\
(1.54)\end{array}$ & $\begin{array}{l}-0.018 \\
(1.26)\end{array}$ & $\begin{array}{c}-0.034^{* *} \\
(2.31)\end{array}$ & $\begin{array}{c}-0.026^{* * *} \\
(3.61)\end{array}$ & $\begin{array}{c}-0.471 * * * \\
(11.48)\end{array}$ \\
\hline Labour force growth $(\mathrm{t}-1)$ & $\begin{array}{l}0.000 \\
(0.04)\end{array}$ & $\begin{array}{l}-0.006 \\
(0.42)\end{array}$ & $\begin{array}{l}-0.011 \\
(0.73)\end{array}$ & $\begin{array}{l}-0.016 \\
(1.09)\end{array}$ & $\begin{array}{l}0.000 \\
(0.02)\end{array}$ & $\begin{array}{l}-0.005 \\
(1.01)\end{array}$ \\
\hline Population density (t-1) & $\begin{array}{l}-0.001 \\
(0.28)\end{array}$ & $\begin{array}{l}-0.001 \\
(0.27)\end{array}$ & $\begin{array}{l}0.002 \\
(0.49)\end{array}$ & $\begin{array}{r}-0.003 \\
(0.60)\end{array}$ & $\begin{array}{l}0.002 \\
(0.31)\end{array}$ & $\begin{array}{l}0.250 \\
(0.88)\end{array}$ \\
\hline ESIF payments $(\mathrm{t}-1)$ & $\begin{array}{c}-2.397 * * * \\
(3.21)\end{array}$ & $\begin{array}{l}-2.022 * * * \\
(2.64)\end{array}$ & $\begin{array}{c}-1.744 * * * \\
(2.82)\end{array}$ & $\begin{array}{l}-2.585^{* * *} \\
(3.44)\end{array}$ & $\begin{array}{l}-0.953^{* * *} \\
(2.97)\end{array}$ & $\begin{array}{l}0.823 \\
(1.49)\end{array}$ \\
\hline GDP growth $(\mathrm{t}-1)$ & $\begin{array}{c}-0.470 * * \\
(2.21)\end{array}$ & $\begin{array}{c}-0.484 * * \\
(2.33)\end{array}$ & $\begin{array}{c}-0.370^{*} \\
(1.77)\end{array}$ & $\begin{array}{l}-0.345 \\
(1.64)\end{array}$ & $\begin{array}{l}-0.157 \\
(0.82)\end{array}$ & $\begin{array}{l}0.039 \\
(0.22)\end{array}$ \\
\hline Share of large farms $(\mathrm{t}-1)$ & $\begin{array}{c}-0.009 \\
(0.19)\end{array}$ & $\begin{array}{r}-0.059 \\
(0.71)\end{array}$ & $\begin{array}{l}-0.082 \\
(1.15)\end{array}$ & $\begin{array}{l}-0.129 \\
(1.54)\end{array}$ & $\begin{array}{l}0.005 \\
(0.18)\end{array}$ & $\begin{array}{c}-0.156^{* * *} \\
(8.54)\end{array}$ \\
\hline Grassland ratio (t-1) & $\begin{array}{c}-0.054^{*} \\
(1.77)\end{array}$ & $\begin{array}{c}-0.054^{*} \\
(1.85)\end{array}$ & $\begin{array}{c}-0.066^{* *} \\
(2.14)\end{array}$ & $\begin{array}{l}-0.041 \\
(1.37)\end{array}$ & $\begin{array}{c}-0.035^{*} \\
(1.69)\end{array}$ & $\begin{array}{l}0.209 \\
(1.22)\end{array}$ \\
\hline $\begin{array}{l}\text { Speed of convergence } \\
\mathrm{R}^{2} \text { (within) }\end{array}$ & 0.054 & 0.030 & 0.018 & 0.035 & 0.061 & 0.291 \\
\hline No. of Observations & 1,587 & 1,587 & 1,587 & 1,587 & 1,587 & 1,587 \\
\hline No. of Instruments & 190 & 189 & 199 & 195 & & \\
\hline $\mathrm{AR}(1) \mathrm{p}$-value & 0.000 & 0.000 & 0.000 & 0.000 & & \\
\hline $\operatorname{AR}(2) p$-value & 0.768 & 0.744 & 0.466 & 0.639 & & \\
\hline Hansen J-Stat. p-value & 0.119 & 0.115 & 0.162 & 0.122 & & \\
\hline Diff-Hansen J-Stat. p-value & 0.715 & 0.887 & 0.876 & 0.556 & & \\
\hline
\end{tabular}

Notes: OLS regression includes time fixed effects; LSDV regression includes region and time fixed effects; SYS-GMM regressions include time fixed effect, and CAP payments, labour force growth and ESIF payments are treated as endogenous. AR(n) is the Arellano and Bond test for serial correlation of first (1) and second (2) order, respectively; Hansen test and Diff-Hansen test are tests for the over-identification restrictions for the validity of instruments. Absolute tstatistics based on clustered standard error by region are reported in parentheses. $* \mathrm{p}<0.10,{ }^{* *} \mathrm{p}<0.05,{ }^{* * *} \mathrm{p}<0.01$. 
Table 3: Convergence regressions for agricultural productivity in OMS (158 regions)

\begin{tabular}{|c|c|c|c|c|c|c|}
\hline $\begin{array}{l}\text { Dependent Variable: } \\
\Delta \text { log VA-Agr. per worker }\end{array}$ & $\begin{array}{c}\text { (1) } \\
\text { SYS-GMM }\end{array}$ & $\begin{array}{c}(2) \\
\text { SYS-GMM }\end{array}$ & $\begin{array}{c}\text { (3) } \\
\text { SYS-GMM }\end{array}$ & $\begin{array}{c}\text { (4) } \\
\text { SYS-GMM }\end{array}$ & $\begin{array}{c}(5) \\
\text { OLS }\end{array}$ & $\begin{array}{l}\text { (6) } \\
\text { FE }\end{array}$ \\
\hline Total CAP subsidy rate $(\mathrm{t}-1)$ & $\begin{array}{c}0.053 * * * \\
(5.48)\end{array}$ & & & & $\begin{array}{l}0.019 \\
(0.80)\end{array}$ & $\begin{array}{l}0.008 \\
(0.34)\end{array}$ \\
\hline Pillar I total (t-1) & & $\begin{array}{l}0.001 \\
(0.04)\end{array}$ & & & & \\
\hline Pillar I coupled $(\mathrm{t}-1)$ & & & $\begin{array}{c}-0.035^{* * *} * \\
\quad(6.29)\end{array}$ & $\begin{array}{c}-0.030 * * \\
(2.07)\end{array}$ & & \\
\hline Pillar I decoupled (t-1) & & & $\begin{array}{c}0.098 * * \\
(2.42)\end{array}$ & $\begin{array}{l}0.102 * * * \\
\quad(3.35)\end{array}$ & & \\
\hline Pillar II total (t-1) & & $\begin{array}{c}0.200 * * * \\
(5.06)\end{array}$ & $\begin{array}{c}0.236^{* * *} \\
(10.10)\end{array}$ & & & \\
\hline Pillar II HK (t-1) & & & & $\begin{array}{l}0.458 \\
(1.11)\end{array}$ & & \\
\hline Pillar II PK (t-1) & & & & $\begin{array}{c}0.417 * * * \\
\quad(3.65)\end{array}$ & & \\
\hline Pillar II ENV (t-1) & & & & $\begin{array}{l}0.319 \\
(0.77)\end{array}$ & & \\
\hline Pillar II LFA (t-1) & & & & $\begin{array}{c}-1.870 * * * \\
(2.97)\end{array}$ & & \\
\hline Pillar II RD (t-1) & & & & $\begin{array}{l}0.121 \\
(0.36)\end{array}$ & & \\
\hline VA-Agr. per worker (t-1) & $\begin{array}{c}-0.140 * * * \\
(4.34)\end{array}$ & $\begin{array}{c}-0.095^{* *} \\
(2.37)\end{array}$ & $\begin{array}{c}-0.060 * \\
(1.91)\end{array}$ & $\begin{array}{c}-0.122 * * * \\
(3.35)\end{array}$ & $\begin{array}{c}-0.025^{*} \\
(1.79)\end{array}$ & $\begin{array}{l}-0.431 * * * \\
\quad(9.26)\end{array}$ \\
\hline Labour force growth $(\mathrm{t}-1)$ & $\begin{array}{c}-0.022 * \\
(1.87)\end{array}$ & $\begin{array}{r}-0.011 \\
(0.74)\end{array}$ & $\begin{array}{l}-0.018 \\
(1.15)\end{array}$ & $\begin{array}{c}-0.024 * \\
(1.66)\end{array}$ & $\begin{array}{r}-0.006 \\
(1.05)\end{array}$ & $\begin{array}{c}-0.011 * \\
(1.77)\end{array}$ \\
\hline Population density (t-1) & $\begin{array}{l}0.002 \\
(0.23)\end{array}$ & $\begin{array}{l}0.002 \\
(0.37)\end{array}$ & $\begin{array}{l}0.006 \\
(1.19)\end{array}$ & $\begin{array}{l}-0.009 \\
(1.50)\end{array}$ & $\begin{array}{l}0.005 \\
(0.99)\end{array}$ & $\begin{array}{l}0.135 \\
(0.44)\end{array}$ \\
\hline ESIF payments $(\mathrm{t}-1)$ & $\begin{array}{c}-4.093 * * \\
(2.39)\end{array}$ & $\begin{array}{c}-3.422 * * \\
(2.03)\end{array}$ & $\begin{array}{l}-2.122 \\
(1.46)\end{array}$ & $\begin{array}{c}-4.069 * * \\
(2.34)\end{array}$ & $\begin{array}{c}-1.177 * * \\
(2.56)\end{array}$ & $\begin{array}{l}-0.367 \\
(0.43)\end{array}$ \\
\hline GDP growth (t-1) & $\begin{array}{l}-0.469 * \\
(1.90)\end{array}$ & $\begin{array}{c}-0.480 * * \\
(2.00)\end{array}$ & $\begin{array}{l}-0.359 \\
(1.37)\end{array}$ & $\begin{array}{l}-0.327 \\
(1.30)\end{array}$ & $\begin{array}{l}-0.106 \\
(0.49)\end{array}$ & $\begin{array}{l}0.013 \\
(0.07)\end{array}$ \\
\hline Share of large farms $(\mathrm{t}-1)$ & $\begin{array}{l}0.008 \\
(0.10)\end{array}$ & $\begin{array}{r}-0.052 \\
(0.48)\end{array}$ & $\begin{array}{l}-0.076 \\
(0.86)\end{array}$ & $\begin{array}{r}-0.091 \\
(1.14)\end{array}$ & $\begin{array}{l}-0.017 \\
(0.49)\end{array}$ & $\begin{array}{c}-0.162 * * * \\
(6.66)\end{array}$ \\
\hline Grassland ratio $(\mathrm{t}-1)$ & $\begin{array}{c}-0.114 * * * \\
(2.68)\end{array}$ & $\begin{array}{c}-0.102 * * \\
(2.15)\end{array}$ & $\begin{array}{c}-0.093^{* *} \\
(2.32)\end{array}$ & $\begin{array}{r}-0.053 \\
(1.18)\end{array}$ & $\begin{array}{c}-0.042 * * \\
(2.08)\end{array}$ & $\begin{array}{l}0.201 \\
(1.46)\end{array}$ \\
\hline $\begin{array}{l}\text { Speed of convergence } \\
\mathrm{R}^{2} \text { (within) }\end{array}$ & 0.151 & 0.100 & 0.062 & 0.130 & 0.050 & 0.252 \\
\hline No. of Observations & 1,276 & 1,276 & 1,276 & 1,276 & 1,276 & 1,276 \\
\hline No. of Instruments & 142 & 146 & 154 & 150 & & \\
\hline AR(1) p-value & 0.000 & 0.000 & 0.000 & 0.000 & & \\
\hline $\operatorname{AR}(2) \mathrm{p}$-value & 0.427 & 0.300 & 0.136 & 0.380 & & \\
\hline Hansen J-Stat. p-value & 0.110 & 0.151 & 0.185 & 0.119 & & \\
\hline Diff-Hansen J-Stat. p-value & 0.880 & 0.942 & 0.995 & 0.648 & & \\
\hline
\end{tabular}

Notes: OLS regression includes time fixed effects; LSDV regression includes region and time fixed effects; SYS-GMM regressions include time fixed effect, and CAP payments, labour force growth and ESIF payments are treated as endogenous. AR(n) is the Arellano and Bond test for serial correlation of first (1) and second (2) order, respectively; Hansen test and Diff-Hansen test are tests for the over-identification restrictions for the validity of instruments. Absolute tstatistics based on clustered standard error by region are reported in parentheses. $* \mathrm{p}<0.10,{ }^{* *} \mathrm{p}<0.05,{ }^{* * *} \mathrm{p}<0.01$. 
Table 4: Convergence regressions for agricultural productivity in NMS (55 regions)

\begin{tabular}{|c|c|c|c|c|c|c|}
\hline $\begin{array}{l}\text { Dependent Variable: } \\
\Delta \text { log VA-Agr. per worker }\end{array}$ & $\begin{array}{c}\text { (1) } \\
\text { SYS-GMM }\end{array}$ & $\begin{array}{c}(2) \\
\text { SYS-GMM }\end{array}$ & $\begin{array}{c}(3) \\
\text { SYS-GMM }\end{array}$ & $\begin{array}{c}(4) \\
\text { SYS-GMM }\end{array}$ & $\begin{array}{l}\text { (5) } \\
\text { OLS }\end{array}$ & $\begin{array}{l}\text { (6) } \\
\text { FE }\end{array}$ \\
\hline Total CAP subsidy rate (t-1) & $\begin{array}{c}0.665^{* *} \\
(2.23)\end{array}$ & & & & $\begin{array}{l}0.043 \\
(0.64)\end{array}$ & $\begin{array}{l}0.035 \\
(0.26)\end{array}$ \\
\hline Pillar I total (t-1) & & $\begin{array}{l}0.232 \\
(0.50)\end{array}$ & & & & \\
\hline Pillar I coupled (t-1) & & & $\begin{array}{c}-2.887 * * \\
(2.06)\end{array}$ & $\begin{array}{r}-1.635 \\
(0.79)\end{array}$ & & \\
\hline Pillar I decoupled (t-1) & & & $\begin{array}{c}1.084^{* *} \\
(2.29)\end{array}$ & $\begin{array}{l}0.939 * * \\
(2.43)\end{array}$ & & \\
\hline Pillar II total (t-1) & & $\begin{array}{l}0.940 \\
(1.18)\end{array}$ & $\begin{array}{l}0.286 \\
(0.66)\end{array}$ & & & \\
\hline Pillar II HK (t-1) & & & & $\begin{array}{l}-2.266 \\
(1.26)\end{array}$ & & \\
\hline Pillar II PK (t-1) & & & & $\begin{array}{c}4.016 * * * \\
(4.52)\end{array}$ & & \\
\hline Pillar II ENV (t-1) & & & & $\begin{array}{l}0.038 \\
(0.04)\end{array}$ & & \\
\hline Pillar II LFA (t-1) & & & & $\begin{array}{l}0.761 \\
(0.37)\end{array}$ & & \\
\hline Pillar II RD (t-1) & & & & $\begin{array}{r}-1.231^{*} \\
(1.79)\end{array}$ & & \\
\hline VA-Agr. per worker (t-1) & $\begin{array}{c}-0.304 * * \\
(2.40)\end{array}$ & $\begin{array}{c}-0.218^{* *} \\
(2.06)\end{array}$ & $\begin{array}{l}0.093 \\
(1.08)\end{array}$ & $\begin{array}{l}-0.091 \\
(1.26)\end{array}$ & $\begin{array}{r}-0.021 \\
(1.59)\end{array}$ & $\begin{array}{c}-0.671 * * * \\
(9.70)\end{array}$ \\
\hline Labour force growth $(\mathrm{t}-1)$ & $\begin{array}{c}0.073 * * \\
(2.22)\end{array}$ & $\begin{array}{l}0.068 * * \\
(2.27)\end{array}$ & $\begin{array}{l}0.070 \\
(1.55)\end{array}$ & $\begin{array}{l}0.061^{* *} \\
(2.22)\end{array}$ & $\begin{array}{l}0.016^{*} \\
(1.96)\end{array}$ & $\begin{array}{l}0.004 \\
(0.57)\end{array}$ \\
\hline Population density (t-1) & $\begin{array}{l}0.082 \\
(0.97)\end{array}$ & $\begin{array}{l}0.048 \\
(0.64)\end{array}$ & $\begin{array}{c}-0.068^{*} \\
(1.69)\end{array}$ & $\begin{array}{l}0.022 \\
(0.51)\end{array}$ & $\begin{array}{l}-0.026 \\
(1.30)\end{array}$ & $\begin{array}{l}0.546 \\
(1.11)\end{array}$ \\
\hline ESIF payments (t-1) & $\begin{array}{l}-5.243 \\
(1.62)\end{array}$ & $\begin{array}{l}-3.515 \\
(1.02)\end{array}$ & $\begin{array}{l}-3.727 \\
(1.58)\end{array}$ & $\begin{array}{c}-5.879 * * \\
(2.50)\end{array}$ & $\begin{array}{r}-1.018 \\
(1.22)\end{array}$ & $\begin{array}{l}0.178 \\
(0.15)\end{array}$ \\
\hline GDP growth $(\mathrm{t}-1)$ & $\begin{array}{l}-0.237 \\
(0.38)\end{array}$ & $\begin{array}{l}-0.389 \\
(0.74)\end{array}$ & $\begin{array}{l}-0.607 \\
(1.06)\end{array}$ & $\begin{array}{l}-0.616 \\
(1.03)\end{array}$ & $\begin{array}{l}-0.291 \\
(0.69)\end{array}$ & $\begin{array}{l}0.128 \\
(0.47)\end{array}$ \\
\hline Share of large farms $(\mathrm{t}-1)$ & $\begin{array}{l}0.483 \\
(1.67)\end{array}$ & $\begin{array}{c}0.354^{*} \\
(1.77)\end{array}$ & $\begin{array}{c}-0.368^{* *} \\
(2.11)\end{array}$ & $\begin{array}{l}-0.014 \\
(0.11)\end{array}$ & $\begin{array}{l}0.015 \\
(0.30)\end{array}$ & $\begin{array}{l}0.237 \\
(0.85)\end{array}$ \\
\hline Grassland ratio (t-1) & $\begin{array}{l}0.053 \\
(0.16)\end{array}$ & $\begin{array}{l}0.010 \\
(0.04)\end{array}$ & $\begin{array}{l}0.059 \\
(0.38)\end{array}$ & $\begin{array}{l}0.203 \\
(1.38)\end{array}$ & $\begin{array}{l}0.000 \\
(0.00)\end{array}$ & $\begin{array}{l}0.261 \\
(0.31)\end{array}$ \\
\hline $\begin{array}{l}\text { Speed of convergence } \\
R^{2} \text { (within) }\end{array}$ & 0.362 & 0.246 & -0.089 & 0.095 & 0.195 & 0.541 \\
\hline No. of Observations & 311 & 311 & 311 & 311 & 311 & 311 \\
\hline No. of Instruments & 37 & 38 & 45 & 49 & & \\
\hline $\mathrm{AR}(1) \mathrm{p}$-value & 0.014 & 0.003 & 0.015 & 0.007 & & \\
\hline $\operatorname{AR}(2) \mathrm{p}$-value & 0.383 & 0.631 & 0.800 & 0.178 & & \\
\hline Hansen J-Stat. p-value & 0.188 & 0.186 & 0.150 & 0.860 & & \\
\hline Diff-Hansen J-Stat. p-value & 0.580 & 0.422 & 0.198 & 0.920 & & \\
\hline
\end{tabular}

Notes: OLS regression includes time fixed effects; LSDV regression includes region and time fixed effects; SYS-GMM regressions include time fixed effect, and CAP payments, labour force growth and ESIF payments are treated as endogenous. AR(n) is the Arellano and Bond test for serial correlation of first (1) and second (2) order, respectively; Hansen test and Diff-Hansen test are tests for the over-identification restrictions for the validity of instruments. Absolute tstatistics based on clustered standard error by region are reported in parentheses. $* p<0.10, * * p<0.05, * * * p<0.01$. 
Appendix 
Table A.1: Absolute convergence in agricultural labour productivity across $\mathrm{EU}$ regions

\begin{tabular}{|c|c|c|c|}
\hline \multirow{2}{*}{$\begin{array}{l}\text { Dependent Variable: } \\
\Delta \text { log VA-Agr. per worker }\end{array}$} & \multicolumn{3}{|c|}{ OLS } \\
\hline & EU-27 & OMS & NMS \\
\hline \multirow[b]{2}{*}{ VA-Agr. per worker (t-1) } & (1) & (2) & (3) \\
\hline & $\begin{array}{c}-0.019 * * * \\
(4.82)\end{array}$ & $\begin{array}{c}-0.015 * * \\
(2.30)\end{array}$ & $\begin{array}{l}-0.034 * * * \\
(3.28)\end{array}$ \\
\hline Speed of convergence & 0.019 & 0.015 & 0.035 \\
\hline $\mathrm{R}^{2}$ & 0.010 & 0.003 & 0.026 \\
\hline No. of Observations & 1587 & 1276 & 311 \\
\hline \multicolumn{4}{|c|}{$\begin{array}{l}\text { Notes: the absolute convergence is estimated by regressing the current year's } \\
\text { growth rate of the agricultural VA per worker on the level of agricultural VA per } \\
\text { worker of the previous year: } \Delta y_{i t}=\alpha+\beta \ln Y_{i t-1}+\varepsilon_{i t} \text {, where } \Delta y_{i t}= \\
\ln Y_{i t}-\ln Y_{i t-1} \text {, denotes region } i \text { 's agricultural labour productivity growth } \\
\text { between time } t \text { and } t-1 ; Y_{i t-1} \text { is the lagged agricultural VA per worker, i.e. the } \\
\text { convergence variable. }\end{array}$} \\
\hline
\end{tabular}


Table A.2: Robustness check with inclusion of outliers in EU-27 (213 regions)

\begin{tabular}{|c|c|c|c|c|c|c|}
\hline $\begin{array}{l}\text { Dependent Variable: } \\
\Delta \text { log VA-Agr. per worker }\end{array}$ & $\begin{array}{c}\text { (1) } \\
\text { SYS-GMM }\end{array}$ & $\begin{array}{c}(2) \\
\text { SYS-GMM }\end{array}$ & $\begin{array}{c}\text { (3) } \\
\text { SYS-GMM }\end{array}$ & $\begin{array}{c}\text { (4) } \\
\text { SYS-GMM }\end{array}$ & $\begin{array}{c}(5) \\
\text { OLS }\end{array}$ & $\begin{array}{l}\text { (6) } \\
\text { FE }\end{array}$ \\
\hline Total CAP subsidy rate $(\mathrm{t}-1)$ & $\begin{array}{c}0.068 * * * \\
(4.29)\end{array}$ & & & & $\begin{array}{l}0.020 \\
(0.93)\end{array}$ & $\begin{array}{l}0.013 \\
(0.51)\end{array}$ \\
\hline Pillar I total $(\mathrm{t}-1)$ & & $\begin{array}{l}0.011 \\
(0.30)\end{array}$ & & & & \\
\hline Pillar I coupled (t-1) & & & $\begin{array}{c}-0.037 * * * \\
\quad(6.08)\end{array}$ & $\begin{array}{l}-0.025 \\
(1.07)\end{array}$ & & \\
\hline Pillar I decoupled (t-1) & & & $\begin{array}{l}0.114 * * * \\
(2.95)\end{array}$ & $\begin{array}{l}0.118 * * * \\
(4.56)\end{array}$ & & \\
\hline Pillar II total (t-1) & & $\begin{array}{l}0.217 * * * \\
(4.25)\end{array}$ & $\begin{array}{l}0.258 * * * \\
(8.75)\end{array}$ & & & \\
\hline Pillar II HK (t-1) & & & & $\begin{array}{l}0.302 \\
(1.03)\end{array}$ & & \\
\hline Pillar II PK (t-1) & & & & $\begin{array}{l}0.378 * * * \\
\quad(3.49)\end{array}$ & & \\
\hline Pillar II ENV (t-1) & & & & $\begin{array}{l}0.667 \\
(1.31)\end{array}$ & & \\
\hline Pillar II LFA (t-1) & & & & $\begin{array}{c}-1.081 * \\
(1.65)\end{array}$ & & \\
\hline Pillar II RD (t-1) & & & & $\begin{array}{l}0.159 \\
(0.51)\end{array}$ & & \\
\hline VA-Agr. per worker (t-1) & $\begin{array}{c}-0.061 * * * \\
(3.65)\end{array}$ & $\begin{array}{c}-0.035^{*} \\
(1.88)\end{array}$ & $\begin{array}{l}-0.022 * \\
(1.68)\end{array}$ & $\begin{array}{c}-0.042^{* * *} \\
(2.99)\end{array}$ & $\begin{array}{c}-0.028 * * * \\
(3.71)\end{array}$ & $\begin{array}{c}-0.470 * * * \\
(11.55)\end{array}$ \\
\hline Labour force growth $(\mathrm{t}-1)$ & $\begin{array}{l}0.005 \\
(0.37)\end{array}$ & $\begin{array}{l}-0.004 \\
(0.29)\end{array}$ & $\begin{array}{l}-0.008 \\
(0.56)\end{array}$ & $\begin{array}{l}-0.009 \\
(0.61)\end{array}$ & $\begin{array}{l}0.001 \\
(0.14)\end{array}$ & $\begin{array}{l}-0.005 \\
(0.96)\end{array}$ \\
\hline Population density (t-1) & $\begin{array}{l}-0.001 \\
(0.18)\end{array}$ & $\begin{array}{l}-0.001 \\
(0.22)\end{array}$ & $\begin{array}{l}0.002 \\
(0.47)\end{array}$ & $\begin{array}{l}-0.003 \\
(0.55)\end{array}$ & $\begin{array}{l}0.002 \\
(0.47)\end{array}$ & $\begin{array}{l}0.164 \\
(0.57)\end{array}$ \\
\hline ESIF payments $(\mathrm{t}-1)$ & $\begin{array}{c}-2.646^{* * *} \\
(3.44)\end{array}$ & $\begin{array}{c}-2.215^{* * *} \\
(3.00)\end{array}$ & $\begin{array}{c}-1.899 * * * \\
(3.16)\end{array}$ & $\begin{array}{c}-2.647 * * * \\
(3.50)\end{array}$ & $\begin{array}{c}-0.990 * * * \\
(3.04)\end{array}$ & $\begin{array}{l}0.727 \\
(1.30)\end{array}$ \\
\hline GDP growth (t-1) & $\begin{array}{c}-0.598 * * \\
(2.27)\end{array}$ & $\begin{array}{c}-0.568 * * \\
(2.46)\end{array}$ & $\begin{array}{c}-0.459 * \\
(1.96)\end{array}$ & $\begin{array}{c}-0.512 * \\
(1.81)\end{array}$ & $\begin{array}{l}-0.214 \\
(1.07)\end{array}$ & $\begin{array}{l}-0.097 \\
(0.42)\end{array}$ \\
\hline Share of large farms (t-1) & $\begin{array}{l}-0.001 \\
(0.02)\end{array}$ & $\begin{array}{l}-0.054 \\
(0.63)\end{array}$ & $\begin{array}{l}-0.079 \\
(1.06)\end{array}$ & $\begin{array}{l}-0.110 \\
(1.28)\end{array}$ & $\begin{array}{l}0.006 \\
(0.24)\end{array}$ & $\begin{array}{c}-0.164 * * * \\
(7.55)\end{array}$ \\
\hline Grass land ratio $(\mathrm{t}-1)$ & $\begin{array}{c}-0.059 * \\
(1.91)\end{array}$ & $\begin{array}{c}-0.058 * \\
(1.92)\end{array}$ & $\begin{array}{c}-0.071 * * \\
(2.25)\end{array}$ & $\begin{array}{l}-0.043 \\
(1.45)\end{array}$ & $\begin{array}{c}-0.040 * \\
(1.87)\end{array}$ & $\begin{array}{l}0.184 \\
(1.04)\end{array}$ \\
\hline $\mathrm{R}^{2}$ (within) & & & & & 0.062 & 0.289 \\
\hline No. of Observations & 1,589 & 1,589 & 1,589 & 1,589 & 1,589 & 1,589 \\
\hline No. of Instruments & 190 & 189 & 199 & 195 & & \\
\hline $\operatorname{AR}(1) p$-value & 0.000 & 0.000 & 0.000 & 0.000 & & \\
\hline $\operatorname{AR}(2) \mathrm{p}$-value & 0.662 & 0.686 & 0.407 & 0.520 & & \\
\hline Hansen J-Stat. p-value & 0.126 & 0.113 & 0.166 & 0.121 & & \\
\hline Diff-Hansen J-Stat. p-value & 0.765 & 0.895 & 0.900 & 0.742 & & \\
\hline
\end{tabular}

Notes: OLS regression includes time fixed effects; LSDV regression includes region and time fixed effects; SYS-GMM regressions include time fixed effect, and CAP payments, labour force growth and ESIF payments are treated as endogenous. AR(n) is the Arellano and Bond test for serial correlation of first (1) and second (2) order, respectively; Hansen's test and Diff-Hansen's test indicate the over-identification restrictions for the validity of instruments. Absolute $\mathrm{t}$-statistics based on clustered standard error by region in parentheses. ${ }^{*} \mathrm{p}<0.10, * * \mathrm{p}<0.05, * * * \mathrm{p}<0.01$. 
Figure A.1: $\sigma$-convergence in agricultural labour productivity across EU regions

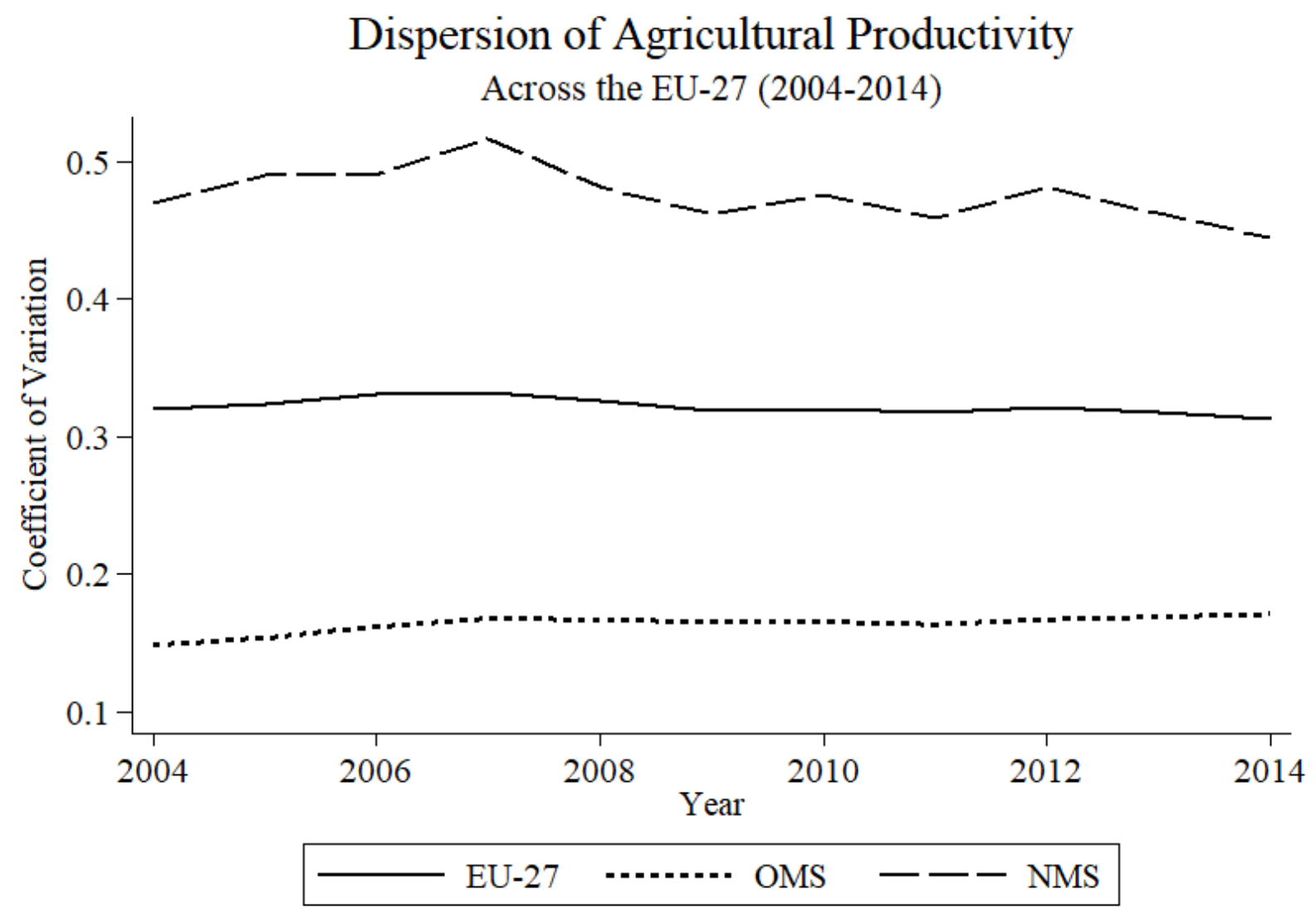

Notes: The coefficient of variation is measured as the cross-sectional standard deviation of the log of agricultural VA per worker relative to the regional mean. 
Table A.3: Robustness check with the exclusion of the ESIF variable in EU-27 (213 regions)

\begin{tabular}{|c|c|c|c|c|c|c|}
\hline $\begin{array}{l}\text { Dependent Variable: } \\
\Delta \text { log VA-Agr. per worker }\end{array}$ & $\begin{array}{c}(1) \\
\text { SYS-GMM }\end{array}$ & $\begin{array}{c}(2) \\
\text { SYS-GMM }\end{array}$ & $\begin{array}{c}\text { (3) } \\
\text { SYS-GMM }\end{array}$ & $\begin{array}{c}\text { (4) } \\
\text { SYS-GMM }\end{array}$ & $\begin{array}{l}(5) \\
\text { OLS }\end{array}$ & $\begin{array}{l}\text { (6) } \\
\text { FE }\end{array}$ \\
\hline Total CAP subsidy rate (t-1) & $\begin{array}{c}0.068 * * * \\
(3.88)\end{array}$ & & & & $\begin{array}{l}0.018 \\
(0.79)\end{array}$ & $\begin{array}{l}0.009 \\
(0.40)\end{array}$ \\
\hline Pillar I total (t-1) & & $\begin{array}{l}0.016 \\
(0.38)\end{array}$ & & & & \\
\hline Pillar I coupled (t-1) & & & $\begin{array}{c}-0.032 * * * \\
(4.41)\end{array}$ & $\begin{array}{c}-0.035^{* *} \\
(2.33)\end{array}$ & & \\
\hline Pillar I decoupled (t-1) & & & $\begin{array}{l}0.106 * * * \\
(2.73)\end{array}$ & $\begin{array}{c}0.120^{* * * *} \\
(4.40)\end{array}$ & & \\
\hline Pillar II total (t-1) & & $\begin{array}{l}0.224 * * * \\
(4.77)\end{array}$ & $\begin{array}{c}0.250 * * * \\
(8.12)\end{array}$ & & & \\
\hline Pillar II HK (t-1) & & & & $\begin{array}{l}0.393 \\
(1.14)\end{array}$ & & \\
\hline Pillar II PK (t-1) & & & & $\begin{array}{l}0.293 * * \\
(2.11)\end{array}$ & & \\
\hline Pillar II ENV (t-1) & & & & $\begin{array}{l}0.534 \\
(1.14)\end{array}$ & & \\
\hline Pillar II LFA (t-1) & & & & $\begin{array}{c}-1.257 * * \\
(2.13)\end{array}$ & & \\
\hline Pillar II RD (t-1) & & & & $\begin{array}{l}0.181 \\
(0.56)\end{array}$ & & \\
\hline VA-Agr. per worker (t-1) & $\begin{array}{c}-0.029 * * * \\
(2.65)\end{array}$ & $\begin{array}{l}-0.007 \\
(0.65)\end{array}$ & $\begin{array}{l}0.002 \\
(0.20)\end{array}$ & $\begin{array}{l}-0.006 \\
(0.56)\end{array}$ & $\begin{array}{c}-0.018 * * * \\
(2.85)\end{array}$ & $\begin{array}{c}-0.469 * * * \\
(11.23)\end{array}$ \\
\hline Labour force growth (t-1) & $\begin{array}{l}0.002 \\
(0.16)\end{array}$ & $\begin{array}{l}-0.005 \\
(0.41)\end{array}$ & $\begin{array}{l}-0.004 \\
(0.33)\end{array}$ & $\begin{array}{l}-0.005 \\
(0.35)\end{array}$ & $\begin{array}{l}0.000 \\
(0.07)\end{array}$ & $\begin{array}{l}-0.005 \\
(1.04)\end{array}$ \\
\hline Population density (t-1) & $\begin{array}{l}0.004 \\
(0.66)\end{array}$ & $\begin{array}{l}0.003 \\
(0.68)\end{array}$ & $\begin{array}{l}0.005 \\
(1.26)\end{array}$ & $\begin{array}{l}-0.001 \\
(0.13)\end{array}$ & $\begin{array}{l}0.004 \\
(0.70)\end{array}$ & $\begin{array}{l}0.156 \\
(0.59)\end{array}$ \\
\hline GDP growth (t-1) & $\begin{array}{c}-0.406^{*} \\
(1.89)\end{array}$ & $\begin{array}{c}-0.503^{* *} \\
(2.45)\end{array}$ & $\begin{array}{c}-0.407 * \\
(1.92)\end{array}$ & $\begin{array}{l}-0.246 \\
(1.12)\end{array}$ & $\begin{array}{l}-0.121 \\
(0.63)\end{array}$ & $\begin{array}{l}0.040 \\
(0.23)\end{array}$ \\
\hline Share of large farms (t-1) & $\begin{array}{l}-0.011 \\
(0.25)\end{array}$ & $\begin{array}{l}-0.066 \\
(0.86)\end{array}$ & $\begin{array}{l}-0.086 \\
(1.28)\end{array}$ & $\begin{array}{l}-0.126^{*} \\
(1.67)\end{array}$ & $\begin{array}{l}0.006 \\
(0.22)\end{array}$ & $\begin{array}{c}-0.159^{* * *} \\
(8.77)\end{array}$ \\
\hline Grassland ratio $(\mathrm{t}-1)$ & $\begin{array}{l}-0.042 \\
(1.55)\end{array}$ & $\begin{array}{c}-0.048 * * \\
(1.98)\end{array}$ & $\begin{array}{c}-0.059 * * \\
(2.10)\end{array}$ & $\begin{array}{l}-0.013 \\
(0.53)\end{array}$ & $\begin{array}{c}-0.030 \\
(1.42)\end{array}$ & $\begin{array}{l}0.225 \\
(1.34)\end{array}$ \\
\hline $\mathrm{R}^{2}$ (within) & & & & & 0.057 & 0.290 \\
\hline No. of Observations & 1,587 & 1,587 & 1,587 & 1,587 & 1,587 & 1,587 \\
\hline No. of Instruments & 146 & 188 & 199 & 206 & & \\
\hline AR(1) p-value & 0.000 & 0.000 & 0.000 & 0.000 & & \\
\hline $\mathrm{AR}(2) \mathrm{p}$-value & 0.857 & 0.824 & 0.479 & 0.710 & & \\
\hline Hansen J-Stat. p-value & 0.003 & 0.105 & 0.162 & 0.133 & & \\
\hline Diff-Hansen J-Stat. p-value & 0.191 & 0.977 & 0.984 & 0.760 & & \\
\hline
\end{tabular}

Notes: OLS regression includes time fixed effects; LSDV regression includes region and time fixed effects; SYS-GMM regressions include time fixed effect and CAP payments and labour force growth are treated as endogenous. AR(n) is the Arellano and Bond test for serial correlation of first (1) and second (2) order, respectively; Hansen test and DiffHansen test indicate the over-identification restrictions for the validity of instruments. Absolute t-statistics based on clustered standard error by region in parentheses. ${ }^{*} \mathrm{p}<0.10, * * \mathrm{p}<0.05, * * * \mathrm{p}<0.01$. 